\title{
A Single Mutation in the Carbohydrate-Binding Module Enhances Cellulase Activity in Bacillus Amyloliquefaciens Mutant
}

\author{
Nitipol POLSA ${ }^{1}$, Chomphunuch SONGSIRIRITTHIGUL ${ }^{2,3}$, \\ Wasana SUYOTHA ${ }^{4}$, Sugunya SUEBSAN ${ }^{5,6}$, \\ Somboon ANUNTALABHOCHAI ${ }^{5,6}$ and Kanta SANGWIJIT ${ }^{6, *}$
}

\author{
${ }^{1}$ Applied Science, School of Science, University of Phayao, Phayao 56000, Thailand \\ ${ }^{2}$ Synchrotron Light Research Institute (Public Organization), Nakhon Ratchasima 30000, Thailand \\ ${ }^{3}$ Center for Biomolecular Structure, Function and Application, Suranaree University of Technology, \\ Nakhon Ratchasima 30000, Thailand \\ ${ }^{4}$ Department of Industrial Biotechnology, Faculty of Agro-Industry, Prince of Songkla University, \\ Songkla 90112, Thailand \\ ${ }^{5}$ Department of Biology, School of Science, University of Phayao, Phayao 56000, Thailand \\ ${ }^{6}$ Plasma Bioengineering Unit, School of Science, University of Phayao, Phayao 56000, Thailand
}

("Corresponding author's e-mail: sangwijit.k@gmail.com)

Received: 27 January 2021, Revised: 20 July 2021, Accepted: 28 July 2021

\begin{abstract}
From our earlier work, we modified the carbohydrate-binding module (CBM) of Bacillus amyloliquefaciens to increase cellulase activity using cold plasma technology. The cellulase gene $(B g l C$ $M$ ) from the mutant was expressed in Escherichia coli BL21(DE3) under the T7 promoter. The hydrolysis activity of the cellulase mutant $(\mathrm{BglC}-\mathrm{M})$ was approximately 2.5 -fold higher than the control $(\mathrm{BglC}-\mathrm{W})$ over a wide range of $\mathrm{pH}$ and temperature conditions. The amino acid sequence of the mutant BglC-M contained 471 residues that were almost identical to the control BglC-W. Only a single amino acid, lysine, was replaced by glutamic acid at position 370 (K370E) within the carbohydrate-binding module (CBM). Structure prediction and substrate docking of BglC-M indicated that the single mutation (K370E) might involve cellulose binding of the $\beta$-sandwich facilitated by hydrogen bonding. The docking study of cellopentaose with the model structure of BglC-M indicated that the replacement of lysine-370 led to the formation of a hydrogen bond with $436 \mathrm{Y}$, which has a shorter distance $(2.6 \AA)$ compared with the control $(5.4 \AA)$. As a result, the structure becomes more compact and stable, resulting in increased catalytic efficiency. Finally, the biomass hydrolysis ability of cellulase was investigated on lignocellulosic wastes such as pineapple peel, corncob, and durian peel. The BglC-M enzyme showed a more significant amount of reducing sugar released from all lignocellulosic wastes than the control. This was the first evidence that altering the base composition of the cellulose binding module enhanced the catalytic activity.
\end{abstract}

Keywords: Agricultural wastes, Bacillus amyloliquefaciens, Carbohydrate-binding module (CBM), Cellulase, Mutation

\section{Introduction}

Because the majority of agricultural waste in Thailand is burned in open fields, it contributes significantly to environmental degradation. In addition, agricultural waste was an inexpensive and renewable resource that could be processed into animal feed [1]. The problems of lignocellulosic materials fed directly to livestock usually include low protein content, high crude fiber, low digestibility 
coefficients, and the presence of some anti-nutrient factors such as tannins and alkaloids [2]. To increase the digestibility of these agricultural residues, it is important to hydrolyze the cellulose chains that interact with each other through hydrogen bonds and form microfibrils [3]. Microorganisms such as fungi, bacteria, and algae have specific enzymes that break down cellulose and convert it into sugars that the organism can readily use as food [4,5]. These enzymes were known as cellulases and were the enzymes that hydrolyze $\beta-1,4$ bonds in cellulose chains. Cellulases have been classified into three major types: endoglucanase (EG, EC 3.2.1.4), cellobiohydrolase (EC 3.2.1.91), and $\beta$-glucosidase (EC 3.2.1.21) [6,7]. Basically, cellulase sequences are composed of catalytic domains (CDs) and carbohydrate-binding modules (CBMs). These were connected by a variety of linkers, differing in length, and sequence [8]. The catalytic module of cellulases is responsible for cleaving $\beta$-1,4- linkages in cellulose polymer in the active site. Moreover, CBMs did not have catalytic activity but functioned as substrate binding modules. The binding property of a CBM improved the enzyme's catalytic function by increasing substrate-enzyme proximity [9,10].B. amyloliquefaciens was an attractive strain for several industrial applications. This strain secretes cellulase and has probiotic attributes, which could apply to many types of animal feed [11]. The production of microbial cellulases in cells is generally regulated by genetic and biochemical approaches involving induction and end-product inhibition [12-14]. These approaches are effective under cellulase production conditions, resulting in limited yields of enzymatic components or their catalysis activity. However, random mutagenesis has been successfully used in Penicillium oxalicum to improve cellulase production [15]. Also, an endoglucanase from Thermotoga maritime Cel5A was subjected to site-directed mutagenesis and CBM engineering to achieve hyperthermostability [16]. Furthermore, a single mutation in a non-catalysis domain of xylanase produced from Bacillus subtilis was performed to increase its hydrolysis activity [17]. This evidence indicated that a single missense mutation caused by a random mutation technique could enhance the catalysis activity of enzymes. More attention has been paid to finding cellulases with higher specific activity, better stability, as well as high affinity for substrate $[18,19]$. To understand these, computer simulations, or in silico techniques, were launched to characterize the properties and structure of proteins. The study was thought to potentially speed up understanding of protein-protein interaction or protein-ligand docking, a method that predicts 1 molecule's preferred orientation in a second when bound to each other to form a stable complex [20].

Cold plasma immersion implantation (P- III) technology has been shown as a novel and highly effective mutagenesis tool. Experimental evidence has shown that energetic ion beam bombardment is an environmentally friendly technique capable of inducing mutations in various living organisms, including crops, fungi, and bacteria [21,22].

In our previous work, $B$. amyloiquefaciens was mutated by cold plasma immersion (P- III) to obtain higher cellulase activity [23]. In this work, the enzyme activity of BglC-M was characterized, and its structure was analyzed. In addition, the model of the 3-dimensional structure of BglC-M was constructed to show the contribution of $\mathrm{K} 370 \mathrm{E}$ to increasing the cellulase activity. This was the first demonstration that a single mutation in the non-catalytic domain (carbohydrate-binding module) was involved in the increase of cellulase enzyme activity $[23,24]$. 


\section{Materials and methods}

\section{Bacterial strains and vectors}

The cellulase producing bacterium, B. amyloliquefaciens $(\mathrm{BglC}-\mathrm{W})$, was mutated and a mutant (BglC-M) was obtained as described in previous work [23]. E. coli strain DH5 $\alpha$ and BL21 (DE3) were used as hosts for transferring plasmids in this work. All bacterial strains were grown at $37{ }^{\circ} \mathrm{C}$ in LuriaBertani (LB) broth and shaken at $120 \mathrm{rpm}$. Cloning and expression vectors, pTZ57R/T and pETDuet-1, were purchased from Thermo Fisher Scientific (USA) and Novagen (USA).

\section{Cellulase gene $(\mathrm{Bg} / \mathrm{C})$ cloning and vector construction}

Chromosomal DNA of the wild-type strain and the mutant was extracted and used as a DNA template for cellulase gene cloning. The known sequences of the cellulase gene from $B$. amyloliquefaciens's registered in GenBank (accession numbers: KY797654.1, MF134665.1 and EU022559.1) were chosen as templates to design primers for amplifying the full-length sequence. Both primers, forward primer 5' ccggcacatatggcagggacaaaaacgccag g 3' with NdeI restriction site, and reverse primer 5' ctaatgctcgaggcctaaagcttaactaatt 3' with XhoI restriction site were designed. Then, the entire cellulase gene sequences of $B g l C-W$ and $B g l C-M$ were amplified by PCR. The 1,416 bp of both PCR products were obtained and subcloned into the pTZ57R/T cloning vector. DNA sequencing was performed using an autosequencer (ABI) by Macrogen, Korea, and nucleotide sequences were determined online with NCBI blast (www.ebi.ac.uk).

Both $B g l C-W$ and $B g l C-M$ were digested with $N d e I$ and $X h o I$ and ligated into the corresponding sites of the pETDuet-1 expression vector. The recombinant plasmids of the mutant and control were transformed into E. coli BL21(DE3), respectively. The transformed cells were cultured on LB plates with $100 \mu \mathrm{g} / \mathrm{ml}$ ampicillin and incubated overnight at $37^{\circ} \mathrm{C}$.

\section{Expression of recombinant $B g l C$ - $W$ and $B g l C$ - $M$ in $E$. coli BL21 (DE3)}

The transformants harboring recombinant $B g l C$ - $W$ and $B g l C$ - $M$ were cultured in LB-ampicillin (100 $\mu \mathrm{g} / \mathrm{ml})$ medium at $28^{\circ} \mathrm{C}$ and shaken at $200 \mathrm{rpm}$ until the $\mathrm{OD}_{600}$ reached 0.6 [17]. The expression of the recombinant cellulase was induced by isopropyl $\beta$-D-1-thiogalactopyranoside (IPTG, $1 \mathrm{mM}$ ) for $12 \mathrm{~h}$ at 28 ${ }^{\circ} \mathrm{C}$. The bacterial cells were harvested by centrifugation followed by ultrasonication. Protein concentration was measured using the Bradford method with bovine serum albumin as standard.

\section{The effect of temperature and $\mathrm{pH}$ on BglC-W and BglC-M hydrolysis activity}

The hydrolysis activity of $\mathrm{BglC}-\mathrm{W}$ and $\mathrm{BglC}-\mathrm{M}$ was assayed using $\mathrm{CMC}$ as a substrate. The effect of $\mathrm{pH}$ was determined by incubating the mixture containing $1 \%(\mathrm{w} / \mathrm{v})$ of CMC with each enzyme at 50 ${ }^{\circ} \mathrm{C}$ for 30 min at $\mathrm{pH} 2.0$ - 11.0. Four different buffers were used: citrate buffer (pH 2.0 - 5.0), potassium phosphate buffer ( $\mathrm{pH} 6.0$ - 7.0), Tris- $\mathrm{HCl}$ buffer $(\mathrm{pH} 8.0-9.0)$ and CAPS buffer $(\mathrm{pH} 9.0-11.0)$. The optimal temperature of each enzyme activity was determined by incubating $1 \%(\mathrm{w} / \mathrm{v})$ substrate with the enzymes in $50 \mathrm{mM}$ citrate buffer $\left(\mathrm{pH} \mathrm{4.0)}\right.$ ) for $30 \mathrm{~min}$ at various temperatures ranging from $10-100{ }^{\circ} \mathrm{C}$. The amount of reducing sugar was determined by the DNS method [25], and the activity at each pH was calculated. All experiments were carried out in triplicate, and the data were expressed as the mean \pm standard deviation. The statistical analysis was analyzed by Duncan's multiple range test, and the values were considered significant at $p<.05$.

Effect of $\mathrm{Ca}^{2+}, \mathrm{Fe}^{2+}$ and EDTA on cellulase activity

The BglC-W and BglC-M in $50 \mathrm{mM}$ citrate buffer ( $\mathrm{pH} 4.0$ ) with $\mathrm{Ca}^{2+}, \mathrm{Fe}^{2+}$ and EDTA were incubated at room temperature for $30 \mathrm{~min}$. The final concentrations of metals and EDTA were 1, 5 and 10 $\mathrm{mM}$. After incubation, the cellulase activities were measured. All experiments were carried out in triplicate, and the data were expressed as the mean \pm standard deviation. The statistical analysis was analyzed by Duncan's multiple range test, and the values were considered significant at $p<.05$. 


\section{Structure prediction and molecular docking of BglC}

ClustalW (1.83) multiple sequence alignment software [26] was chosen for amino-acid sequence alignment. After that, ESPript [27] was linked to illustrate the secondary structure of the templates selected. The catalytic core of $\mathrm{BglC}$ was aligned with that obtained from B. subtilis cellulase 5A (PDB code 3PZT). The carbohydrate-binding module of mutant $\mathrm{K} 370 \mathrm{E} \mathrm{BglC}$ and $B$. subtilis cellulase $5 \mathrm{~A}$ (PDB code $2 \mathrm{~L} 8 \mathrm{~A}$ ) were aligned.

The structural models of BglC were created using SWISS-MODEL [28]. The model of the catalytic domain of BglC was built by using the X-ray structure PDB code 3PZT, and the carbohydrate-binding module of BglC-M was built using PDB code $2 \mathrm{~L} 8 \mathrm{~A}$, which corresponded to a family of 5 catalytic domains and a family of 3 carbohydrate-binding modules (CBM3), respectively.

The coordinates of divalent cations $\left(\mathrm{Ca}^{2+}\right.$ and $\left.\mathrm{Fe}^{2+}\right)$ were simulated within the catalytic core of the model structure. In addition, the coordinates of cellopentaose were docked into the carbohydrate-binding module of the predicted structure of BglC-M. Docking studies in both catalytic and carbohydrate-binding domains were performed by AutoDock Vina [29]. Finally, all structures were displayed with PyMOL [30].

Analysis of the hydrolysis of cellulases against lignocellulosic substrates

The hydrolysis activities of $\mathrm{BglC}-\mathrm{W}$ and $\mathrm{BglC}-\mathrm{M}$ were determined using lignocellulosic substrates including pineapple peel, corncob, and durian peel. The hydrolysis activities were carried out by incubating the enzyme in $50 \mathrm{mM}$ citrate buffer with $5 \%(\mathrm{w} / \mathrm{v})$ substrates for 7 days at $50{ }^{\circ} \mathrm{C}$. Then, the reaction mixtures were collected every $24 \mathrm{~h}$. The reducing sugar released from the substrates was measured by the DNS method. All experiments were carried out in triplicate, and the data were expressed as the mean \pm standard deviation. The statistical analysis was analyzed by Duncan's multiple range test, and the values were considered significant at $p<0.05$.

\section{Results and discussion}

Cloning and sequence analysis of $\mathrm{BglC}$

B. amyloliquefaciens was induced mutation by P-III in our previous work, and the mutant with greater cellulase activity was described [23]. Sequence comparison between cellulase genes of the wild type $(B g l C-W)$ and the mutant $(B g l C-M)$ revealed that $B g l C-W$ and $B g l C-M$ consisted of 1,416 nucleotides, encoding a protein of 471 amino acids. The amino acid sequence alignment of BglC-W and BglC-M was almost identical. However, a single amino acid, lysine, located at position 370, was substituted with glutamic acid (K370E). Analysis of the conserved domain further confirmed that our cellulase gene was comprised of the catalytic domain (from 1M to 301I), which belongs to family 5 of glycoside hydrolases (GH5) and a family 3 cellulose binding module (CBM3) (from 326I to 471H). A catalytic domain (CD) and a family 3 carbohydrate-binding module (CBM3) were connected by a short linker sequence (from $302 \mathrm{~L}$ to $325 \mathrm{G}$ ). Based on sequence alignment and domain analysis, the mutant residue $(\mathrm{K} 370 \mathrm{E})$ was situated in $\mathrm{CBM} 3$, not in the catalytic site.

\section{Characterization of cellulase enzymes}

Our previous study [31] B. amyloliquefaciens was selected as a microorganism source for cellulase production and applied for animal feed. However, the more stable and higher catalytic activity of enzymes under a broad range of $\mathrm{pH}$ and temperature is required for a feed fermentation process. Both cellulase genes ( $B g l C-W$ and $B g l C-M$ ) were subcloned and introduced into host cells, then incubated with $1 \% \mathrm{CMC}$ in $\mathrm{pH}$ ranging from 2 to 11 . The reducing sugar was liberated from the reaction and measured by using the DNS method, and the activity of the enzyme was also calculated. As shown in Figure 1, cellulase activity of $\mathrm{BglC}-\mathrm{W}$ and $\mathrm{BglC}-\mathrm{M}$ attained the highest values at $\mathrm{pH}$ 4.0. The effect of temperature on cellulase activities was measured, and the result is shown in Figure 2. he highest activity of BglC-M was observed at $50{ }^{\circ} \mathrm{C}$, and its cellulase activity was approximately 2.5 times higher over a wide range of $\mathrm{pH}$ and temperature, retaining approximately $80 \%$ of the activity at $90{ }^{\circ} \mathrm{C}$ after 30 minutes of incubation (Figure 2). During the feed fermentation process, the temperature within the fermented chamber 
increased gradually, up to $42{ }^{\circ} \mathrm{C}$ [32]. Therefore, our mutant had higher catalytic activity between 40 - 60 ${ }^{\circ} \mathrm{C}$, which was suitable for the fermented process.

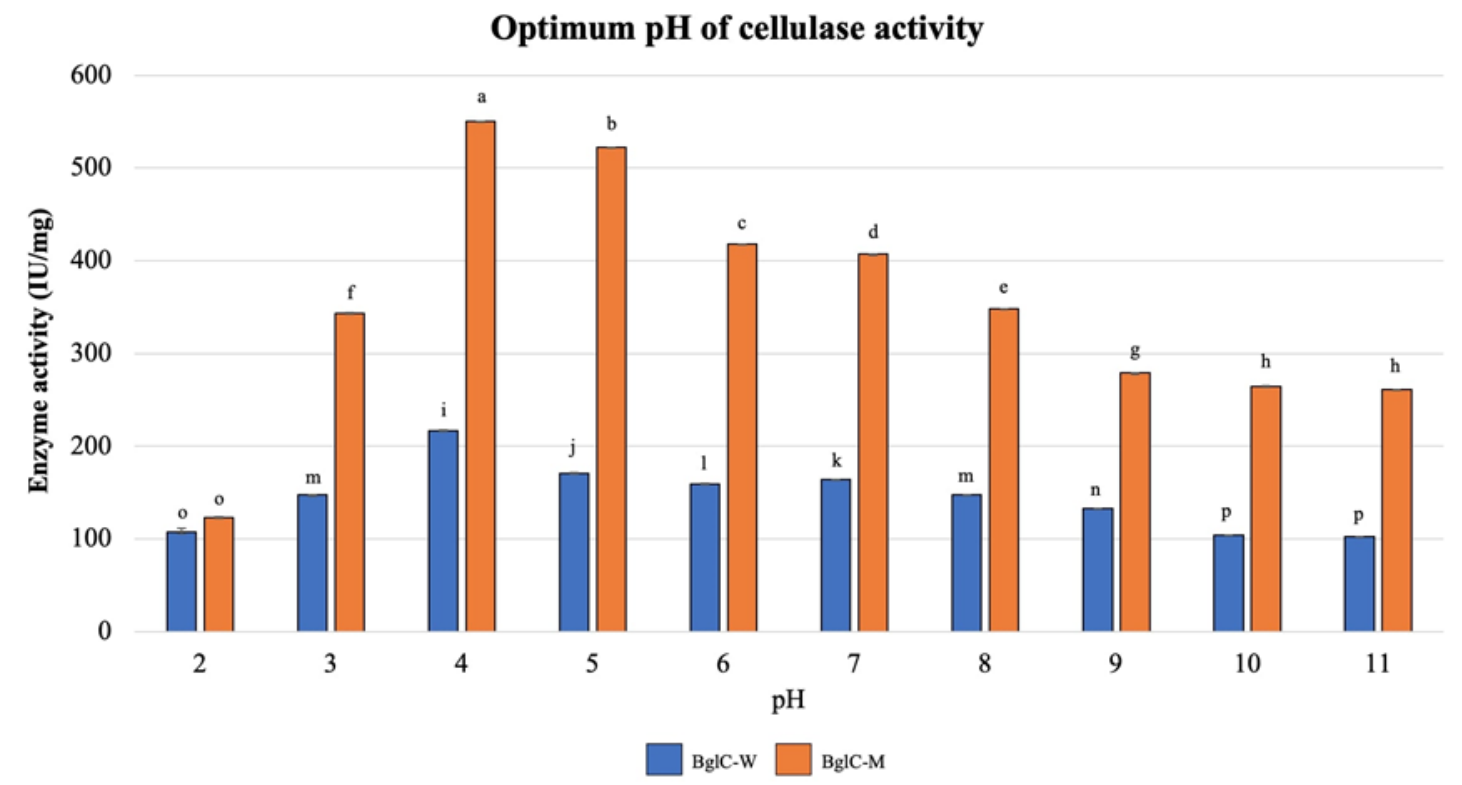

Figure 1 Cellulase activities of BglC-W and BglC-M at different $\mathrm{pH}$ ranging from $\mathrm{pH} 2-11$ at $50^{\circ} \mathrm{C}$. The letters indicate a significant difference $(p<0.05)$ as determined by Duncan's multiple range test.

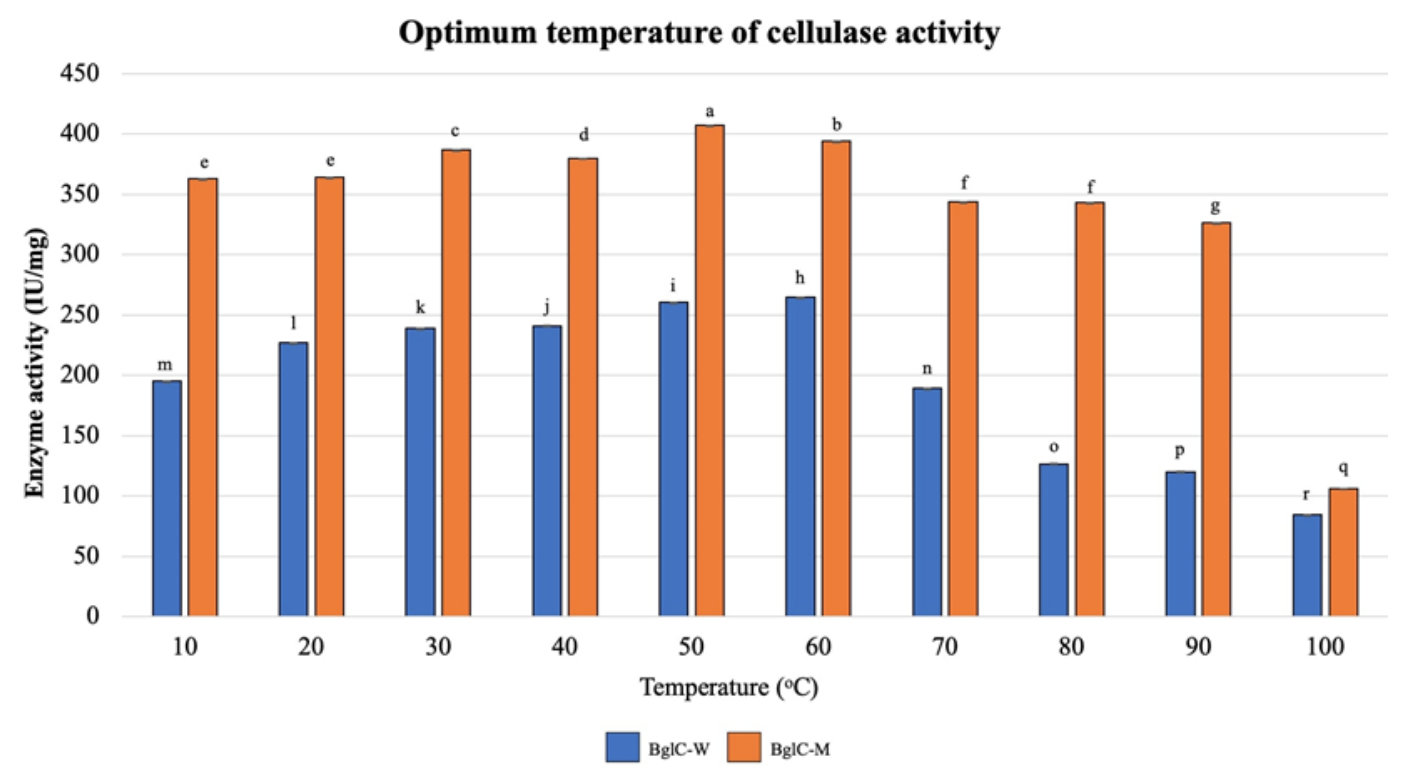

Figure 2 Cellulase activities of BglC-W and BglC-M at different temperature ranging from $10-100^{\circ} \mathrm{C}$. The letters indicate a significant difference $(p<0.05)$ as determined by Duncan's multiple range test. 
The effects of $\mathrm{Ca}^{2+}, \mathrm{Fe}^{2+}$ and chelating agents

As shown in Table 1, the effect of $\mathrm{Ca}^{2+}$ and $\mathrm{Fe}^{2+}$ on cellulase activity of BglC-W and BglC-M was reported. The effects of these ions proved to be dependent on their concentration. Under the lowest concentration of $1 \mathrm{mM}, \mathrm{Ca}^{2+}$ and $\mathrm{Fe}^{2+}$ were able to increase cellulolytic activity slightly. The activity of both enzymes slightly increased in the presence of $\mathrm{Ca}^{2+}$ and $\mathrm{Fe}^{2+}$ at low concentrations, but it decreased when ion concentrations increased. In contrast, increasing EDTA concentration provided only a slight decrease in enzyme activity under given conditions.

Presumably, the docked metal atoms $\left(\mathrm{Ca}^{2+}\right.$ and $\left.\mathrm{Fe}^{2+}\right)$ were coordinated by the side chains of polar serine and asparagine residues, carbonyl oxygen, and the amide nitrogen. The metal binding motif with the possible hepta coordination may contribute to its stability, thus further enhancing cellulase activity. Such a metal binding site had been previously reported for the crystal structure of the catalytic core of $B$. subtilis cellulase 5A [33]. Yaniv et al. [34] also confirmed that the role of metal ions was to facilitate holding the loop together, but not for protein reconformation. And EDTA was a strong chelating agent and effectively removed divalent cation concentrations from the catalytic domain, thus eliminating the metal-binding motif and suggesting lower stability. Therefore, the range of 1 to $10 \mathrm{mM}$ of EDTA reduced cations, resulting in decreased stability and activity of the enzyme.

Table 1 Effect of ions and chelating agent on cellulase activity

\begin{tabular}{ccccccccc}
\hline & \multicolumn{2}{c}{$\begin{array}{c}\text { Relative } \\
\text { cellulase activity }\end{array}$} & \multicolumn{2}{c}{ BglC-W } & & \multicolumn{2}{c}{ BglC-M } & \\
\hline \multirow{2}{*}{$\mathbf{0 ~ m M}$} & $\mathbf{1 ~ m M}$ & $\mathbf{5 ~ m M}$ & $\mathbf{1 0 ~ m M}$ & $\mathbf{0 ~ m M}$ & $\mathbf{1 ~ m M}$ & $\mathbf{5 ~ m M}$ & $\mathbf{1 0 ~ m M}$ \\
$\mathrm{Ca}^{2+}$ & $100.00 \pm 0.11^{\mathrm{c}}$ & $103.57 \pm 0.36^{\mathrm{b}}$ & $94.14 \pm 0.11^{\mathrm{d}}$ & $81.44 \pm 0.21^{\mathrm{g}}$ & $100.00 \pm 0.25^{\mathrm{c}}$ & $115.97 \pm 0.47^{\mathrm{a}}$ & $92.57 \pm 0.21^{\mathrm{e}}$ & $88.66 \pm 0.39^{\mathrm{f}}$ \\
$\mathrm{Fe}^{2+}$ & $100.00 \pm 0.28^{\mathrm{b}}$ & $110.27 \pm 0.05^{\mathrm{a}}$ & $53.14 \pm 0.45^{\mathrm{e}}$ & $45.97 \pm 0.01^{\mathrm{f}}$ & $100.00 \pm 0.47^{\mathrm{b}}$ & $100.10 \pm 0.07^{\mathrm{b}}$ & $80.52 \pm 0.24^{\mathrm{c}}$ & $66.30 \pm 0.12^{\mathrm{d}}$ \\
EDTA & $100.00 \pm 0.34^{\mathrm{a}}$ & $73.34 \pm 0.15^{\mathrm{f}}$ & $74.20 \pm 0.35^{\mathrm{e}}$ & $64.19 \pm 0.22^{\mathrm{g}}$ & $100.00 \pm 0.30^{\mathrm{a}}$ & $83.29 \pm 0.31^{\mathrm{c}}$ & $86.60 \pm 0.30^{\mathrm{b}}$ & $80.54 \pm 0.23^{\mathrm{d}}$ \\
\hline
\end{tabular}

The letters indicate a significant difference $(p<0.05)$ as determined by Duncan's multiple range test.

\section{Structural comparison between BglC-W and BglC-M \\ Sequence analysis of the cellulase enzyme}

The sequence's alignment between the control (BglC-W) and mutant (BglC-M) $B$. amyloliquefaciens cellulases (BaCel5) was shown in Figure 3. Analysis of the conserved domain (Figure 3) confirmed that our $\mathrm{BglC}$ gene belonged to a cellulase superfamily, consisting of a GH5 family catalytic domain (CD 301 residues) and a family 3 cellulose-binding module (CBM3 $\sim 144$ residues), according to CAZy classification (http://www.cazy.org). The 2 domains were joined by a short linker sequence (302LGSKDSTKERPETPAQDNPAQENG327), which was rich in hydrophobic residues. Based on sequence alignment and domain analysis, the mutant residue (K370E) was suggested to be located in CBM3, not the catalytic motif. Typically, carbohydrate-binding modules (CBMs) are amino acid sequences that play an important role in carbohydrate-binding [35]. The alignment result showed that our CBM belongs to family 3 CBM (CBM3), which forms a planar surface for cellulose recognition [35]. The aromatic residues that contribute to its planar carbohydrate-binding site, assumingly conduct the substrate in a proper conformation to the active site, thus being considered in our molecular docking studies of cellopentaose. This would be further discussed in detailed information. 

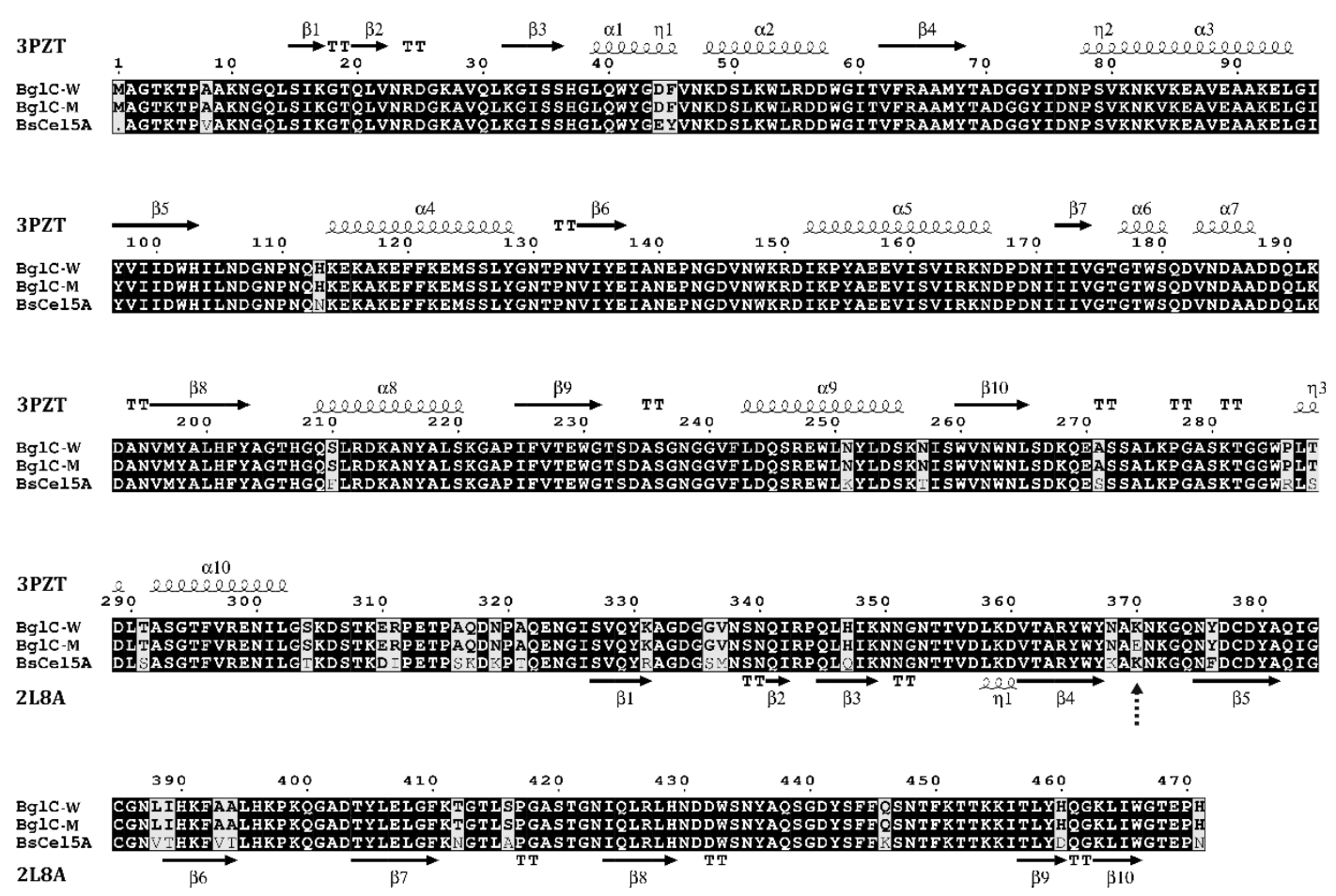

Figure 3 Amino acid sequence alignment of wild type and mutant cellulase from B. amyloliquefaciens (BglC-W and BglC-M, respectively) and cellulase from B. subtilis 168 (BsCel5A). Secondary structures were predicted using the X-ray structures of the catalytic domain and carbohydrate-binding module of $\mathrm{BsCel5A}$ as templates (PDB entries 3PZT and 2L8A, respectively). The catalytic domain is shown above the sequences, but the carbohydrate-binding module is below the sequences. The mutant residue (K370E) was indicated by a dashed arrow. $\alpha$-helices and $\beta$-strands are displayed as squiggles and arrows, respectively. TT indicates turns. Fully conserved residues are printed as white characters on a black background. Similar residues are written in black bold characters and boxed.

\section{Analysis of BglC catalytic core}

The catalytic core of BsCel5A (PDB code 3PZT) was used as a template to compare with that of BglC. The alignment result showed that our cellulase shared $96 \%$ amino acid identity with the catalytic core of the structural template. In the previous report, the BsCel5A catalytic core structure was composed of a typical $(\beta / \alpha) 8$-TIM-barrel domain with the catalytic residues located on $\beta$-strands [33]. Structural analysis revealed that the model structure of the catalytic core of our cellulase displayed a common TIM barrel fold. $\mathrm{Ca}^{2+}$ and $\mathrm{Fe}^{2+}$ were docked in the model structure of the catalytic core, thus having the same binding free energy (in $\mathrm{kcal} / \mathrm{mol}$ ) of -1.4 . Docking studies presume that the coordination of metal ions by serine and asparagine may stabilize enzyme structure and lead to an increase in its cellulolytic activity. $\mathrm{Fe}^{2+}$ and $\mathrm{Co}^{2+}$ have been previously reported to increase the enzyme activity of endocellulase Cel-5A under the low concentration of $1 \mathrm{mM}[36]$. Moreover, the $\mathrm{Co}^{2+}$ ion in the endoglucanase CelCM3 was able to enhance the enzyme activity [37]. Metal ions have been proposed to guide the enzyme into its optimized and stabilized conformation $[33,38]$. The contribution of metal ions in our study may facilitate the enzyme structure becoming more stable, thus further increasing its activity. 


\section{Analysis of BglC carbohydrate-binding module (CBM3)}

BglC-W and BglC-M CBM3 amino acid sequences shared 90 and 89 percent sequence identity, respectively, with $\mathrm{BsCel} 5 \mathrm{~A}$ ( $\mathrm{PDB}$ code $2 \mathrm{~L} 8 \mathrm{~A}$ ) as a template model. The predicted structure revealed that CBM3 folded into a $\beta$-sandwich, a dominant fold among CBMs. It comprised $2 \beta$-sheets which consisted of 4 and 5 antiparallel $\beta$-strands, being similar to the selected template (Figure 4). There is also one short -helix similar to BsCel5A at the C-terminus of the predicted structure (Figure 4). The structure of cellopentaose docked in the structure of BglC-M had a binding free energy of $-7.5 \mathrm{kcal} / \mathrm{mol}$.

From the docking study, $376 \mathrm{Y}$ is close to the reducing end terminal residue of the substrate $(\sim 8 \AA$ apart), which may facilitate the occupation of the substrate. 376Y is proposed to lie along with the hydrophobic platform since it may form a hydrophobic stack against the pyranose rings of the incoming cellulose chain (Figure 4). From the docking study of cellopentaose with the model structure of BglC-M, the residues which were proposed to form hydrogen bonds with cellopentaose were $370 \mathrm{E}$ of BglC-M and 398K of BsCel5A CBM3 (homologous to 370K of BglC-W) (Figure 4). The oxygen atom of the sugar residue at the non-reducing end (subsite -3 ) recognizes the side chain oxygen of $370 \mathrm{E}$ and the amide side chain of $398 \mathrm{~K}$ with the predicted hydrogen bond distances of 3.8 and $3.6 \AA$, respectively (Figure 4). $398 \mathrm{~K}$ of BsCel5A CBM3 (homologous to $370 \mathrm{~K}$ of BglC-W) was located on a surface loop, and its amide side chain was far from the hydroxyl side chain of 464Y (BsCel5A CBM3) with the distance of $5.4 \AA$, thus being predicted in BglC-W similarly. The predicted hydrogen bonding with the distance of $2.6 \AA$ between $370 \mathrm{E}(\mathrm{BglC}-\mathrm{M})$ and $436 \mathrm{Y}$, which linked the flexible loops together, thus making the structure more compact. This might increase the stability of the enzyme and collectively contribute to the accommodation of the cellulose chain. Our biochemical assays indicated that the K370E mutant exhibited approximately 2.5 times the activity improvement when compared to the wild type. Docking studies of BglC-M CBM3 with cellopentaose reported that the carbohydrate-binding site is involved in a hydrophobic stack against the pyranose rings and hydrogen bonds formed between the hydroxyl groups of cellopentaose and the model protein.

The backbone carbonyl of 370E of BglC-M was structurally homologous to $398 \mathrm{~K}$ of BsCel5A and was proposed to form a hydrogen bond within the sugar ring at subsite -2, with a distance of $3.0 \AA$ (Figure 4). Similarly, the backbone carbonyl of $373 \mathrm{G}$ formed a hydrogen bond with the oxygen atom of the sugar residue (subsite -1) docked at a predicted distance of $3.9 \AA$ (Figure 4). The glucosyl substrate at subsite -2 is proposed to be stacked against the indole ring of $433 \mathrm{~W}$ (Figure 4).

Two aromatic residues on this face were $433 \mathrm{~W}$ and $436 \mathrm{Y}$, whereas $376 \mathrm{Y}$ was buried in the $\beta$ sandwich core, making hydrophobic contacts. The findings indicated that the interactions of BglC CBM3 with cellulose were contributed by aromatic residues and polar side chains. Yaniv et al. [34] found that base substitution by site mutagenesis from asparagine to tryptophan (N126W) in the carbohydrate binding domain enhanced the binding ability of cellulase from Clostidium thermocellum, thus proposing its crystal structure. However, the activity of the cellulase was not demonstrated.

Thermostability and $\mathrm{pH}$ stability generated from the mutants are also the keys to the improvement of enzyme properties and activities [39]. Moreover, CBM played an important role in substrate binding, which further enhanced the catalytic activity [40] and thermostability [41]. Our study showed that a mutant, which involved in the alteration of a single charged residue in the CBM3 domain by P-III enhanced its cellulase activity. 


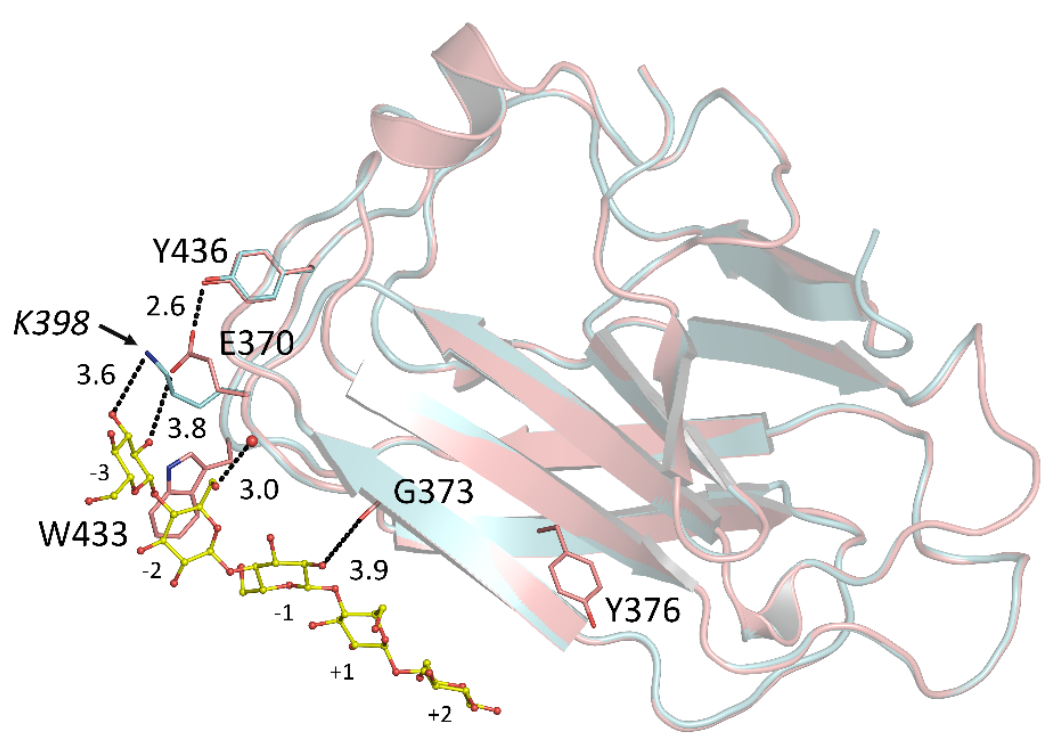

Figure 4 The superposed structures of the cellulose binding domain. The structure model of BglC-M from B. amyloliquefaciens was shown in salmon. The structure of BsCel5A CBM3 from B. subtilis 168 (PDB code 2L8A) was shown in cyan. The residues involved in carbohydrate recognition in the structure model of BglC-M K370E were shown as a stick model with carbon in salmon, nitrogen in blue, and oxygen in red. $398 \mathrm{~K}$, labeled in italic, was from the structure of BsCel5A CBM3 shown as a stick model with carbon in cyan. The docked cellopentaose was shown as a ball-and-stick model with carbon in yellow. Sugar-binding subsites were labeled. The black dashed line represented a predicted hydrogen bond formed in the structure model of BglC-M between the surrounding residues and the cellopentaose molecule; their distances are given in $\AA$.

\section{Hydrolysis activities on lignocellulosic substrates}

The hydrolysis activity of cellulases on pineapple peel, corncob, and durian peel was tested. The results showed an increase in hydrolysis activity by measuring the amount of reducing sugar liberated from substrates since the first day of incubation. As shown in Figure 5, the results indicated that BglC-M exhibited the highest hydrolysis activity against all substrates. The most suitable substrate for this experiment was the corncob since it released the highest amount of reducing sugar on the $7^{\text {th }}$ day.

According to the composition of lignocellulosic biomass, which contains $45-55 \%$ of cellulose, the reducing sugar released during our experiment could be calculated as $20-40 \%$ of total cellulose in each lignocellulosic substrate. This result indicated that the mutant could be used to hydrolyze these lignocellulosic wastes for animal feed. In the future, this cellulase mutant would be applied to hydrolyze lignocellulosic wastes for fermented animal feed, particularly corncob and durian peel. This could provide low-cost animal feed and reduce air pollution by avoiding the burning of lignocellulosic waste. 
The hydrolysis activity of each substrate

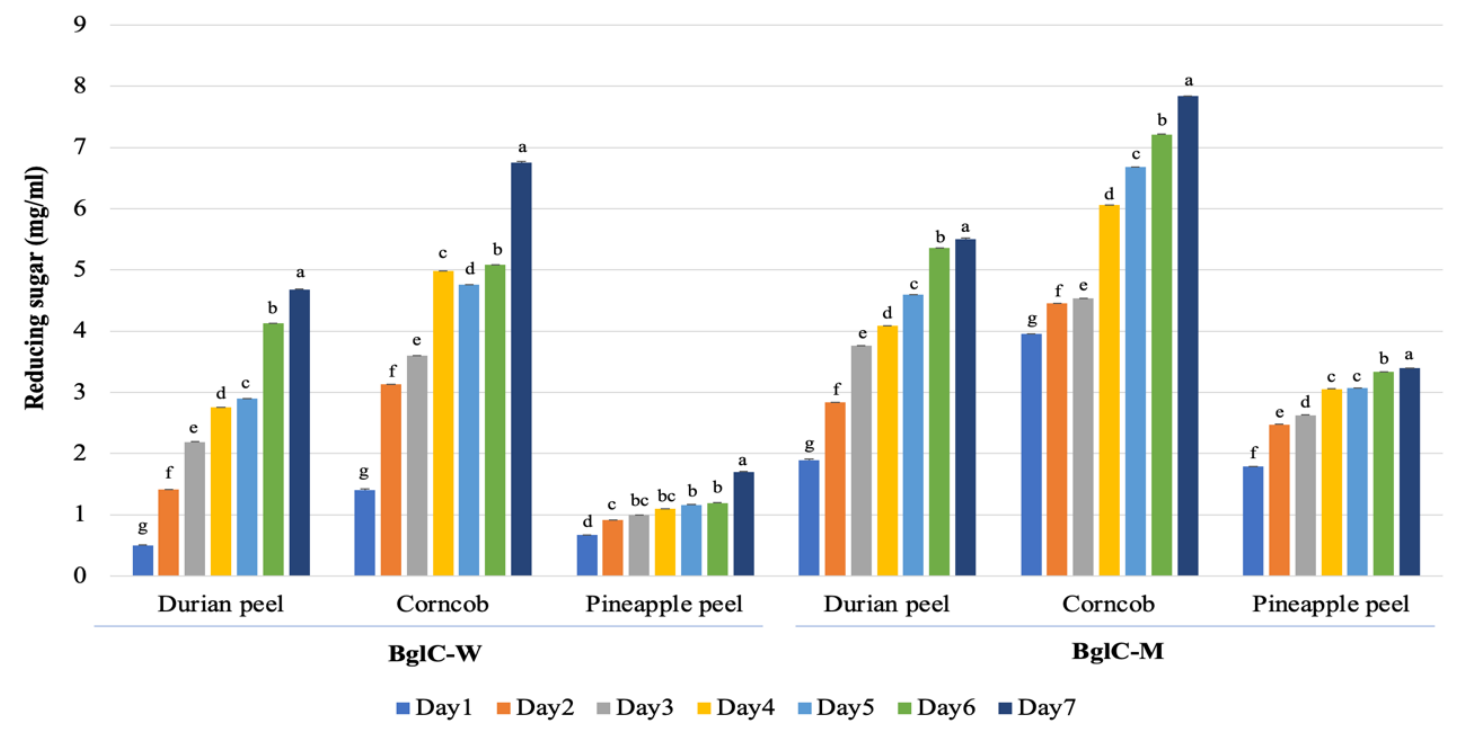

Figure 5 Hydrolysis activity of BglC-W and $\mathrm{BglC}-\mathrm{M}$ on durian peel, corncob, and pineapple peel. The letters indicate a significant difference $(p<.05)$ as determined by Duncan's multiple range test.

\section{Conclusions}

By using cold plasma implantation, B. amyloliquefaciens was mutated to increase its cellulase activity. Under a wide variety of temperature and $\mathrm{pH}$ conditions, the cellulase mutant (BglC-M) demonstrated about 2.5-fold greater catalytic activity than the control. The molecular docking study proposed the carbohydrate-aromatic and hydrogen bonding interactions between cellopentaose and BglC. Moreover, the residue which recognized the incoming substrate was predicted. Sequence analysis and structure prediction revealed that a single amino acid residue substituted from lysine to glutamine at position $370(\mathrm{~K} 370 \mathrm{E})$ in the cellulose binding module, while not in the catalytic domain. The predicted structure of BglC-M with bound substrate revealed the role of mutant K370E, thus facilitating the attachment of the 2 loops. This amino acid (K370E) involved a charge residue change on the CBM3, resulting in increased structural stability and enzymatic activity. In addition, the hydrolysis ability of cellulase was investigated on agricultural wastes, including pineapple peel, corncob, and durian peel. A greater release of reducing sugar was detected in the corncob. Although an amino acid mutation in CBM $(\mathrm{N} 126 \mathrm{~W})$ increasing the binding activity of $C$. thermocellum cellulase has been reported [34], its enzyme activity was not demonstrated. This was the first evidence shown that a single amino acid substitution in $\mathrm{CBM}$, not in the catalytic domain, increased its enzyme activity.

\section{Acknowledgements}

This research was supported by the Thailand Center of Excellence in Physics, Chiang Mai University, Unit of Excellence (FF64-UoE036) and the School of Science, University of Phayao. The authors have no conflict of interest to declare. 
http://wjst.wu.ac.th

\section{References}

[1] T Hasunuma, F Okazaki, N Okai, KY Hara, J Ishii and A Kondo, A review of enzymes and microbes for lignocellulosic biorefinery and the possibility of their application to consolidated bioprocessing technology. Bioresour. Technol. 2013; 153, 513-22.

[2] AM Kholif, MA El-Ashry, HA El-Alamy, HM El-Sayed, M Fadel and SM Kholif. Biological treatments banana wastes for feeding lactating goats. Egypt. J. Nutr. Feeds 2005; 8, 149-62.

[3] J Pérez, J Muñoz-Dorado, T de la Rubia and J Martínez, Biodegradation and biological treatments of cellulose, hemicellulose, and lignin: An overview. Int. Microbiol. 2002; 5, 53-63.

[4] LT Angenent, K Karim, MH Al-Dahlan, BA Wrenn and R Domiquez-Espinosa. Production of bioenergy and biochemicals from industrial and agricultural wastewater. Trends. Biotechnol. 2004; 22, 477-85.

[5] HH Azzaz. 2009, Effect of cellulytic enzymes addition to diets on the productive performance of lactating goats. Master Thesis. Cairo University, Cairo, Egypt.

[6] J Hong, H Tamaki, S Akiba, K Yamamoto and H Kumagai. Cloning of a gene encoding a highly stable endo-beta-1,4-glucanase from Aspergillus niger and its expression in yeast. J. Biosci. Bioeng. 2001; 92, 434-41.

[7] YH Li, M Ding, J Wang, GJ Xu and F Zhao. A novel thermoacidophilic endoglucanase, Ba-EGA, from a new cellulose-degrading bacterium, Bacillus sp. AC-1. Appl. Microbiol. Biotechnol. 2006; 70, 430-6.

[8] M Kurasin and P Väljamäe. Processivity of cellobiohydrolases is limited by the substrate. J. Biol. Chem. 2011; 286, 169-77.

[9] AB Boraston, DN Bolam, HJ Gilbert and GJ Davies. Carbohydrate-binding modules: Fine-tuning polysaccharide recognition. Biochem. J. 2004; 382, 769-81.

[10] V Lombard, H Golaconda Ramulu, E Drula, PM Coutinho and B Henrissat. The carbohydrateactive enzymes database (CAZy) in 2013. Nucleic. Acids Res. 2014; 42, D490-D495.

[11] R Du, S Jiao, Y Dai, J An, J Lv, X Yan, J Wang and B Han. Probiotic bacillus amyloliquefaciens C-1 improves growth performance, stimulates GH/IGF-1, and regulates the gut microbiota of growth-retarded beef calves. Front. Microbiol. 2018; 9, 2006.

[12] OS Kotchoni, O Shonukan and WE Gachomo. Bacillus pumilus BpCRI 6 a promising candidate for cellulase production under conditions of catabolite repression. Afr. J. Biotechnol. 2003; 2, 1406.

[13] M Mandels, J Weber and R Parizek. Enhanced cellulase production by a mutant of Trichoderma viride. Appl. Microbiol. 1971; 21, 152-4.

[14] DE Eveleigh and BS Montenecourt. Increasing yields of extracellular enzymes. Adv. Appl. Microbiol. 1979; 25, 57-74.

[15] G Liu, L Zhang, Y Qin, G Zou, Z Li, X Yan, X Wei, M Chen, L Chen, K Zheng, J Zhang, L Ma, J Li, R Liu, H Xu, X Bao, X Fang, L Wang, Y Zhong, W Liu, H Zheng, S Wang, C Wang, L Xun, GP Zhao, T Wang, Z Zhou and Y Qu. Long-term strain improvements accumulate mutations in regulatory elements responsible for hyper-production of cellulolytic enzymes. Sci. Rep. 2013; 3, 1569.

[16] SA Mahadevan, SG Wi, DS Lee and HJ Bae. Site-directed mutagenesis and CBM engineering of Cel5A (Thermotoga maritima). FEMS. Microbiol. Lett. 2008; 287, 205-11.

[17] N Polsa, W Suyotha, S Suebsan, S Anuntalabhochai and K Sangwijit. Increasing xylanase activity of Bacillus subtilis by atmospheric pressure plasma jet for biomass hydrolysis. 3 Biotech. 2020; 10, 22.

[18] SP Voutilainen, T Puranen, M Siika-Aho, A Lappalainen, M Alapuranen, J Kallio, S Hooman, L Viikari, J Vehmaanperä and A Koivula. Cloning, expression, and characterization of novel thermostable family 7 cellobiohydrolases. Biotechnol. Bioeng. 2008; 101, 515-28.

[19] AV Gusakov. Alternatives to Trichoderma reesei in biofuel production. Trends Biotechnol. 2011; 29, 419-25. 
http://wjst.wu.ac.th

[20] T Lengauer and M Rarey. Computational methods for biomolecular docking. Curr. Opin. Struct. Biol. 1996; 6, 402-6.

[21] K Naito, M Kusaba, N Shikazono, T Takano, A Tanaka, T Tanisaka and M Nishimura. Transmissible and nontransmissible mutations induced by irradiating Arabidopsis thaliana pollen with gamma-rays and carbon ions. Genetics 2005; 169, 881-9.

[22] KP Gopinath, S Murugesan, J Abraham and K Muthukumar. Bacillus sp. mutant for improved biodegradation of congo red: Random mutagenesis approach. Bioresour. Technol. 2009; 100, 6295-300.

[23] K Sangwijit, J Jitonnom, S Pitakrattananukool, LD Yu and S Anuntalabhochai. Low-energy plasma immersion ion implantation modification of bacteria to enhance hydrolysis of biomass materials. Surf. Coat. Technol. 2016; 306, 336-40.

[24] F Islam and N Roy. Screening purification and characterization of cellulase from cellulase producing bacteria in molasses. BMC Res. Notes 2018; 11, 1-6.

[25] GC Miller. Use of dinitrosalicylic acid reagent for determination of reducing sugar. Anal. Chem. $1959 ; 31,426-8$.

[26] MA Larkin, G Blackshields, NP Brown, R Chenna, PA McGettigan, H McWilliam, F Valentin, IM Wallace, A Wilm, R Lopez, JD Thompson, TJ Gibson and DG Higgins. Clustal W and Clustal $\mathrm{X}$ version 2.0. Bioinformatics 2007; 23, 2947-8.

[27] X Robert and P Gouet. Deciphering key features in protein structures with the new ENDscript server. Nucleic. Acids Res. 2014; 42, W320-W324.

[28] A Waterhouse, M Bertoni, S Bienert, G Studer, G Tauriello, R Gumienny, FT Heer, TAP de Beer, C Rempfer, L Bordoli, R Lepore and T Schwede. SWISS-MODEL: Homology modelling of protein structures and complexes. Nucleic. Acids Res. 2018; 46, W296-W303.

[29] O Trott and AJ Olson, AutoDock Vina: Improving the speed and accuracy of docking with a new scoring function, efficient optimization, and multithreading. J. Comput. Chem. 2010; 31, 455-61.

[30] The PyMOL Molecular Graphics System, Available at: http://pymol.sourceforge.net/overview/index.htm, accessed June 2019.

[31] R Kalawong, M Wakayama, S Anuntalabhochai, C Wongsawad and K Sangwijit. Comparison and characterization of purified cellulase and xylanase from Bacillus amyloliquefaciens CX1 and Bacillus subtilis B4. Chiang. Mai. J. Sci. 2018; 45, 92-105.

[32] P McDonald, AR Henderson and R Whittenbury. The effect of temperature on ensilage. J. Sci. Food Agric. 1966; 17, 476-80.

[33] CR Santos, JH Paiva, ML Sforça, JL Neves, RZ Navarro, J Cota, PK Akao, ZB Hoffmam, AN Meza, JH Smetana, ML Nogueira, I Polikarpov, J Xavier-Neto, FM Squina, RJ Ward, R Ruller, AC Zeri and MT Murakami. Dissecting structure-function-stability relationships of a thermostable GH5-CBM3 cellulase from Bacillus subtilis 168. Biochem. J. 2012; 441, 95-104.

[34] O Yaniv, S Petkun, L Shimon, B Edward, R Lamed and F Frolow. A single mutation reforms the binding activity of an adhesion-deficient family 3 carbohydrate-binding module. Acta Crystallogr. D. Biol. Crystallogr. 2012; 68, 819-28.

[35] AB Boraston, DN Bolam, HJ Gilbert and GJ Davies. Carbohydrate-binding modules: Fine-tuning polysaccharide recognition. Biochem. J. 2004; 382, 769-81.

[36] L Ma, R Aizhan, Wang, X Wang, Y Yi, Y Shan, B Liu, Y Zhou and X Lu. Cloning and characterization of low-temperature adapted GH5-CBM3 endo-cellulase from Bacillus subtilis $1 \mathrm{AJ} 3$ and their application in the saccharification of switchgrass and coffee grounds. AMB Expr. $2020 ; 10,42$.

[37] KK Ghadikolaei, J Gharechahi, K Haghbeen, K Noghabi, GH Salekdeh and H Zahiri. A coldadapted endoglucanase from camel rumen with high catalytic activity at moderate and low temperatures: An anomaly of truly cold-adapted evolution in a mesophilic environment. Extremophiles 2018; 22, 315-26. 
http://wjst.wu.ac.th

[38] XX Yan, XM An, LL Gui and DC Liang. From structure to function: Insights into the catalytic substrate specificity and thermostability displayed by Bacillus subtilis mannanase BCman. J. Mol. Biol. 2008; 379, 535-44.

[39] F Contreras, S Pramanik, AM Rozhkova, N Zorov, OI Korotkova, AP Sinitsyn, U Schwaneberg, and MD Davari. Engineering robust cellulases for tailored lignocellulosic degradation cocktails. Int. J. Mol. Sci. 2020; 21, 1589.

[40] SF Badino, SJ Christensen, J Kari, MS Windahl, S Hvidt, K Borch and P Westh. Exo-exo synergy between Cel6A and Cel7A from Hypocrea jecorina: Role of carbohydrate binding module and the endo-lytic character of the enzymes. Biotechnol. Bioeng. 2017; 114, 1639-47.

[41] P Westh, K Borch, T Sørensen, R Tokin, J Kari, S Badino, MA Cavaleiro, N Røjel, S Christensen, CS Vesterager and C Schiano-di-Cola. Thermoactivation of a cellobiohydrolase. Biotechnol. Bioeng. 2018; 115, 831-8. 